\title{
Transformation of endometrium and fertility in late stages of pseudopregnancy in the rabbit
}

\author{
B. Fischer, E. Winterhager and L. C. Busch* \\ Abteilung Anatomie und Reproduktionsbiologie, Medizinische Fakultät, RWTH Aachen, \\ Melatener Straße 211, D-5100 Aachen, Federal Republic of Germany
}

\begin{abstract}
Summary. Ovulation was induced in rabbits between Days 14 and 18 of pseudopregnancy by an intravenous injection of hCG. Induction of ovulation from Day 16 onwards led to normal progestational endometrial transformation. In rabbits injected on Day 14 or 15 , a normal preimplantation endometrial morphology developed, but not earlier than 7 days after hCG (Day 14/15 +7). Uteroglobin secretion was advanced during the second pseudopregnancy. After mating or artificial insemination, fertility was greatest on Day 18 of pseudopregnancy. Conception failed on Day 14 and embryo transfers were unsuccessful on Day $14+1$. Transfers performed on Day $14+3$, however, led to implantation and offspring, even though endometrial morphology did not correspond to the normal Day 3 preimplantational morphology at the time of transfer.

We conclude that (1) endometrial transformation typical of normal pseudopregnancy can be induced by ovulation during the regeneration phase of pseudopregnancy from Day 16 onwards; (2) fertilization and implantation can be achieved as early as Day 15 of pseudopregnancy; (3) an oestrous period with high mating activity and fertility occurs about 3 days later; and (4) Day 14 after hCG represents a limited time of functional change from pseudopregnancy to a fertile uterine cycle in the rabbit.
\end{abstract}

\section{Introduction}

In the pseudopregnant rabbit corpora lutea begin to regress about Day 12 after hCG (Hilliard, 1973). Luteal regression is indicated by decreasing concentrations of progesterone in blood serum (Harrington \& Rothermel, 1977; Carlson \& Gole, 1978; Ellinwood, Seidel \& Niswender, 1979; Browning, Keyes \& Wolf, 1980) and by typical morphological features of the endometrial epithelium (Arnold \& Shorey, 1984; Busch, Winterhager \& Fischer, 1986).

In the present study, induction of ovulation by a second hCG injection or by mating in later stages of pseudopregnancy, i.e. between Days 14 and 18 after hCG, and its effects on endometrial regeneration and on fertility have been investigated.

\section{Materials and Methods}

A total of 190 sexually mature female rabbits of mixed breed was used. The does were caged individually for at least 3 weeks in a controlled environment with $12 \mathrm{~h}$ light/ $24 \mathrm{~h}$ before induction of ovulation by 100 i.u. human chorionic gonadotrophin (hCG) i.v. (Prolan: Bayer, Leverkusen, FRG). The day of hCG injection was designated Day 0.

\footnotetext{
* Present address: Institut für Anatomie, Medizinische Universität zu Lübeck, Ratzeburger Allee 160, D-2400 Lübeck, Federal Republic of Germany.
} 
Mating and artificial insemination (AI) studies. Artificial insemination (AI) was performed on Day 14, 15, 16, 17 or 18 according to Schlegel, Fischer, Beier \& Schneider (1983). After $28 \mathrm{~h}$ the does were killed by a rapid intravenous injection of pentobarbitone sodium $(75 \mathrm{mg} / \mathrm{kg}$ ) (Nembutal: Abbott, CEVA, Bad Segeberg, FRG), the excised oviducts were flushed, and the eggs examined for 2- and 4-cell stages using a stereomicroscope (magnification $\times 20-40$ ).

Part of the study, investigating mating behaviour and fertility, was performed as a field trial at the farm of our rabbit supplier in November, which is a poor breeding season for the rabbit. This time was chosen to minimize variation due to receptivity of the does. On Days 14, 16, 18, 20, 22 or 24 , respectively, does (10 per day) were placed with bucks of proven fertility and the numbers of females mating and litters were recorded for each experimental day.

Embryo transfer experiments. About $3 \mathrm{~h}$ after recovery, embryos were transferred (5-8 per side) to recipients of the Day 14 series in which ovulation had been induced 1 or 3 days before transfer. Embryos were transferred into the oviducts (Day 1 embryos, 1 day after second ovulation) or into the uteri (Day 3 embryos, 3 days after second ovulation). Embryos were obtained from FSHprimed donors by flushing the oviducts and uteri, respectively, using Maurer's medium (Maurer, 1978) supplemented with $1.5 \%$ BSA. Transfers were performed by laparotomy through a mid-line incision and anaesthesia induced by $5 \mathrm{mg}$ perphenazine/rabbit (Decentan: Merck, Darmstadt, FRG) i.m. and $40 \mathrm{mg}$ thiobarbitone sodium $/ \mathrm{kg}$ (Thiogenal: Merck) given i.v. Implantation sites were evaluated on Day 12 either by re-laparotomy or by killing the recipients.

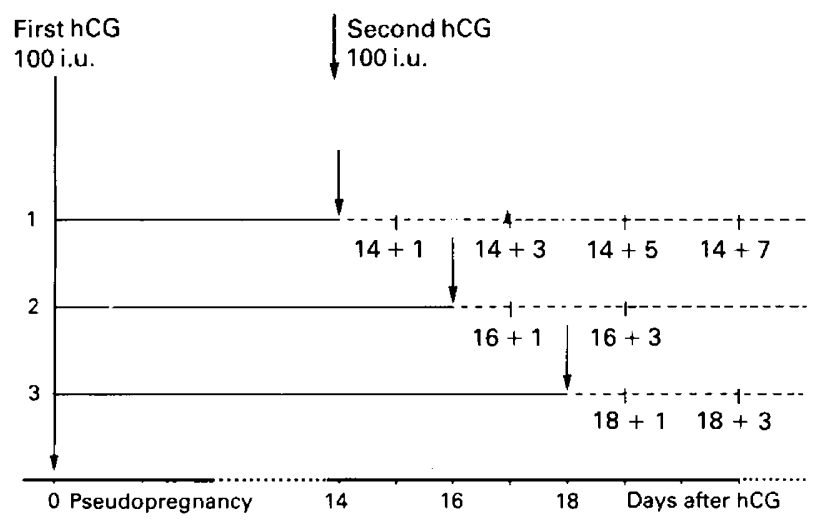

Fig. 1. Experimental schedule for induction of ovulation in later stages of pseudopregnancy ( $\geq 3$ rabbits/group for morphological studies, $\geq 2$ for biochemical analysis). The experimental groups investigated were: Day $14+1,+3,+5,+7$; Day $15+1,+3$; Day $16+1,+3$; Day 17 $+1,+3$; Day $18+1,+3,+5,+7$.

Biochemical investigations. Uterine flushings were collected from rabbits, killed as described above, 1, 3, 5 or 7 days after the second hCG injection. The experimental groups are listed in Fig. 1. They are referred to as Day $14+1$, Day $14+3, \ldots$, Day $18+7$ (Fig. 1). The flushings were analysed for relative percentage of uteroglobin by disc gel electrophoresis (Beier, 1968, 1974, 1982; Maurer, 1971). Briefly, electrophoresis was performed in glass tubes using $7 \cdot 5 \%$ polyacrylamide and a Tris-glycine buffer ( $\mathrm{pH} \mathrm{9 \cdot 1).} \mathrm{After} \mathrm{staining} \mathrm{with} \mathrm{amido} \mathrm{black} \mathrm{and} \mathrm{destaining} \mathrm{the} \mathrm{gel} \mathrm{tubes}$ were quantitatively evaluated by densitometry. The coefficients of variation (CV) were calculated by separating a randomly chosen sample 5 times in 3 different electrophoretic runs. The inter-assay CV was $28 \%$ and the intra-assay CV varied between 4 and $13 \%$. 


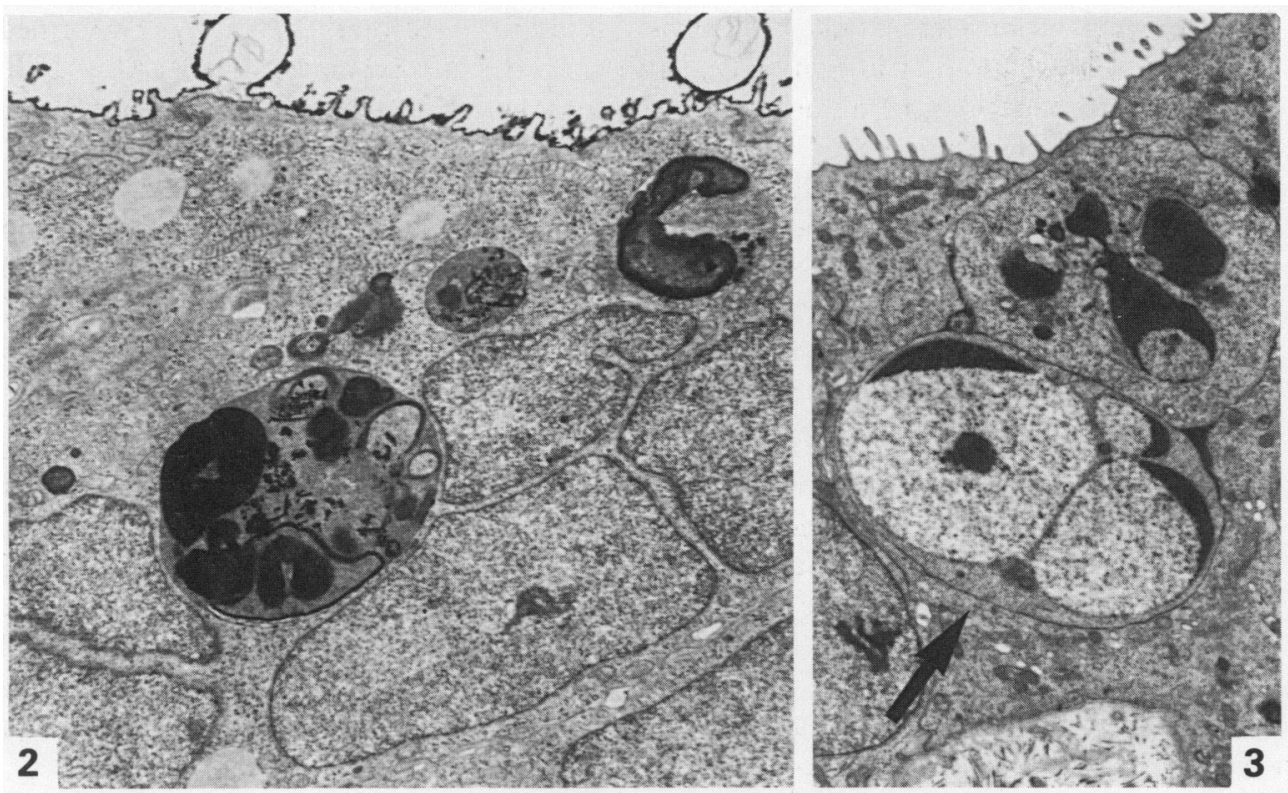

Fig. 2. Symplasm of uterine epithelium on Day $14+3$. The multinucleated symplasm contains large secondary lysosomes with multilamellar sheets. $\times 7300$.

Fig. 3. Uterine epithelial cell (Day $14+3$ ) exhibiting an apoptotic nucleus (arrow) as indicated by condensed chromatin at the margin of the nucleus. $\times 6000$.

Morphological investigations. On Days 14, 15, 16, 17 and 18 (all at +3 and +7 ), uteri of nulliparous does were fixed by perfusion and processed for freeze-fracture, transmission (TEM) or scanning electron microscopy (SEM) as described by Winterhager, Busch \& Kühnel (1984).

Hormone assays. Peripheral blood samples were taken ( 3 rabbits/group) at Days 14-18 and Days 14-18+1, $+3,+5$, and +7 , respectively. Plasma concentrations of progesterone were measured by radioimmunoassay ([ $\left.{ }^{3} \mathrm{H}\right]$ PROG-RIA 100: Institut National des Radioelements, Fleurus, Belgium) using an anti-rabbit progesterone antiserum. The samples were diluted 1:10 before measurement. The sensitivity of the assay is $7 \pm 5 \cdot 1 \mathrm{pg} /$ assay tube. The intra-assay CV was $11 \%$ and the interassay CV was $15 \cdot 6 \%$. Plasma oestradiol-17 $\beta$ was determined by ${ }^{125}$ I-labelled oestradiol RIA ER 155 (Radio Isotopen Service, Würenlingen, Switzerland) with a sensitivity of $5 \mathrm{pg} / \mathrm{ml}$, an intra-assay $\mathrm{CV}$ of $7 \%$ and an inter-assay $\mathrm{CV}$ of $9.6 \%$. The oestradiol antiserum had been raised in rabbits.

Statistical analysis. Uteroglobin relative percentage values and hormone concentrations were subjected to statistical analyses by Duncan's multiple range test.

\section{Results}

\section{Morphology of the endometrial epithelium}

Epithelial morphology on Day $14+3$ and Day $15+3$ revealed striking differences compared to normal Day 3 endometrial transformation. Indications of cell destruction characterized the epithelial ultrastructure (Figs 2 \& 3). Numerous, large symplasms which are normally not formed before Day 6 of pseudopregnancy (Winterhager et al., 1984; Busch et al., 1986) were still present (Figs 2 \& 4) 


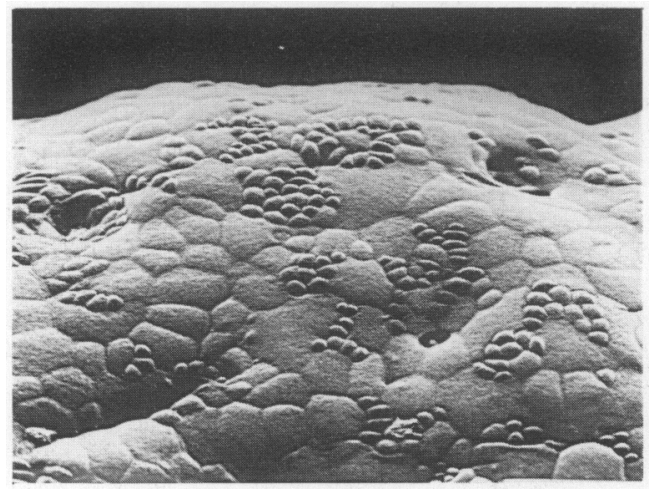

Fig. 4. Scanning electron micrograph of a Day $14+3$ uterine epithelium. Numerous symplasms can be recognized with intercalated groups of epithelial cells. $\times 200$.

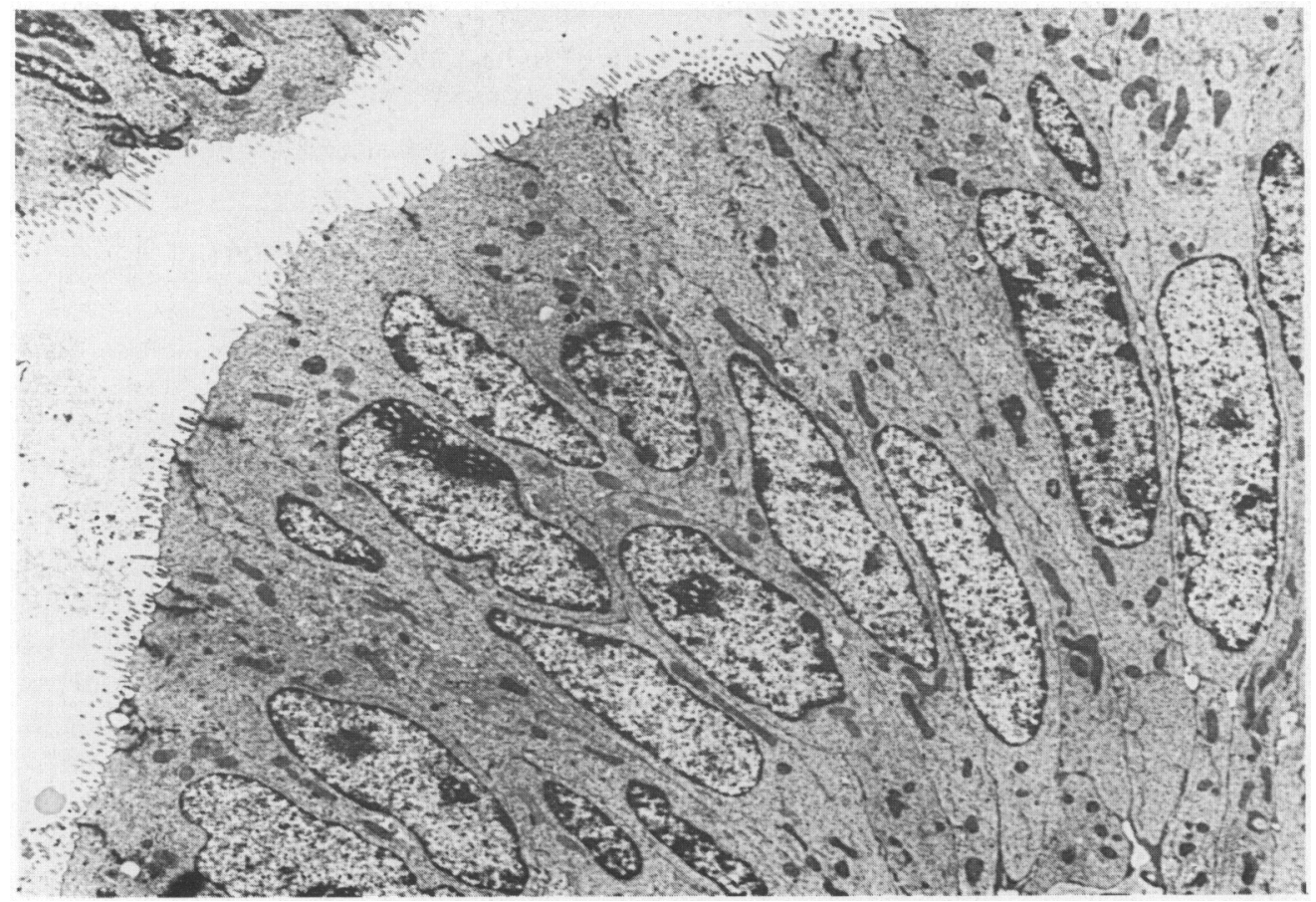

Fig. 5. Uterine epithelium on Day $15+3$ demonstrating that part of the epithelium consists of columnar epithelial cells with ovoid nuclei. $\times 4300$.

originating from the preceding cycle. These symplasms were obviously undergoing lysis, as indicated by large autophagic lysosomes in different stages of conversion and by cells with degenerating apoptotic nuclei (Figs $2 \& 3$ ). Sporadically, in Day $15+3$ animals, small areas of columnar epithelium occurred such as are found in nonpregnant endometrium (Fig. 5).

In freeze-fracture replicas of Day $14+3$ uteri, a broad tight junctional belt, comparable to those seen on Day 14 of pseudopregnancy (Busch et al., 1986), was still present (Fig. 6). An epithelium 
resembling that of the corresponding normal pseudopregnant stage was found not earlier than 7 days after hCG if hCG was given on Days 14/15 of pseudopregnancy. Typical morphological features for Day 7 of pseudopregnancy include dome-shaped cell protrusions, highly proliferated tight junctional belts (Fig. 7), and first signs of newly formed symplasms (Fig. 8). SEM overviews of the mucosal folds indicated that epithelial proliferation was sometimes slightly reduced in Days $14 / 15+7$ uteri.

In contrast to Days $14 / 15$, induction of ovulation as early as 1 day later, on Day 16 of pseudopregnancy, led to a normal endometrial transformation on Day $16+3$. In normal pseudopregnant rabbits, i.e. with no second induction of ovulation, however, remnants of former symplasms and indications of cell destruction are still present on Day 16 (Busch et al., 1986). Like those for Day 16, the Day 17 and 18 series showed a normal progestational endometrial transformation.

\section{Uteroglobin secretion}

Compared to uteroglobin concentration in normal pseudopregnant rabbits, ovulation during late stages of pseudopregnancy led to an earlier secretion of uteroglobin 3 days after hCG (Fig. 9;
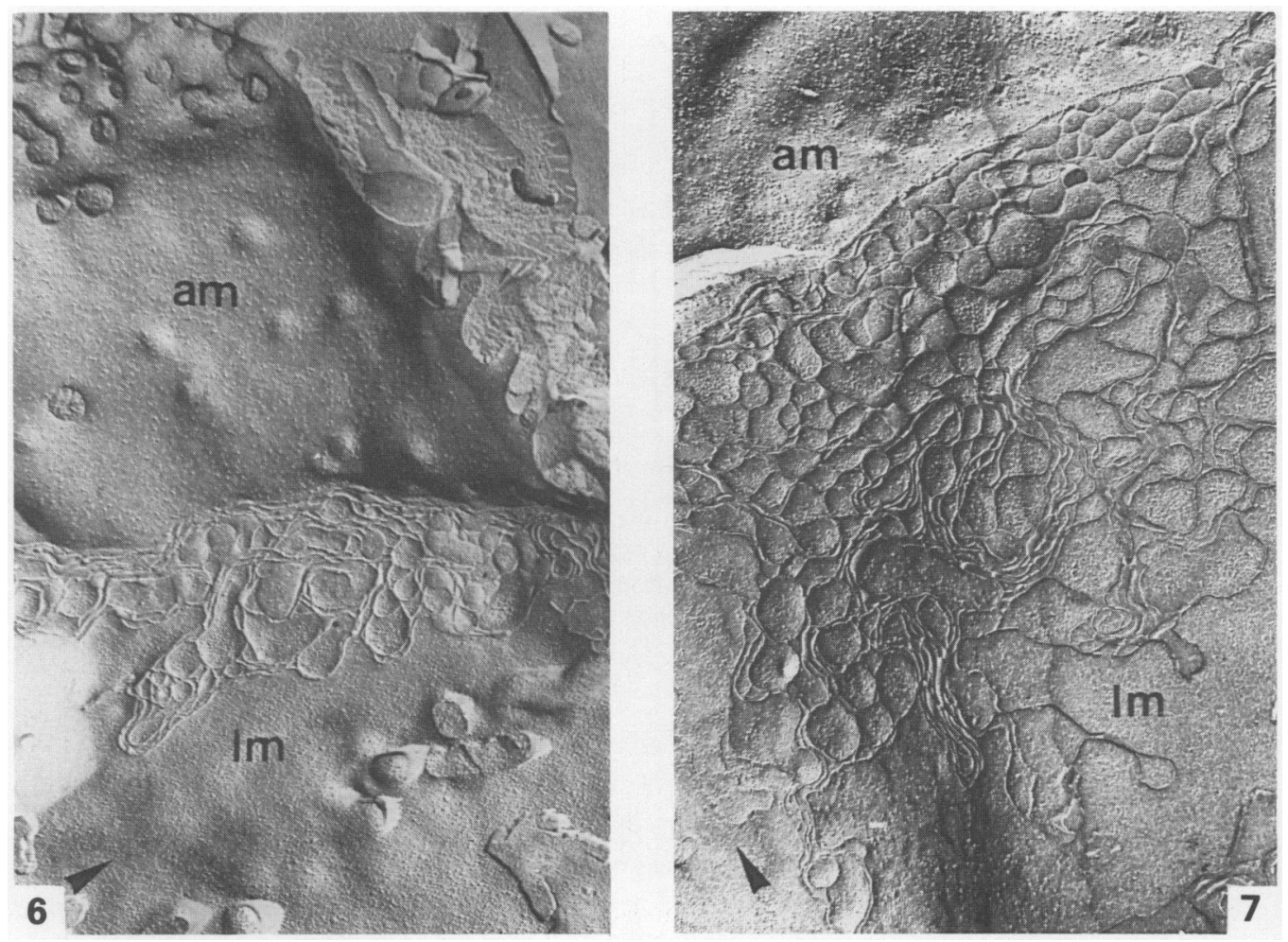

Fig. 6. Freeze-fracture replica of a uterine epithelial cell from a Day $14+3$ animal. The lateral membrane exhibits a broad tight junctional belt similar to that of a Day 14 animal. The arrowhead indicates the direction of shadowing. am, apical membrane; lm, lateral membrane. $\times 22000$.

Fig. 7. Freeze-fracture replica of a uterine epithelial cell at Day $14+7$. The tight junctional belt is greatly proliferated with strands running perpendicular to the uterine lumen. Such a proliferated tight junction is comparable to that of a Day 7 pregnant or pseudopregnant animal. The arrowhead indicates the direction of shadowing. am, apical membrane; lm, lateral membrane. $\times 27500$. 


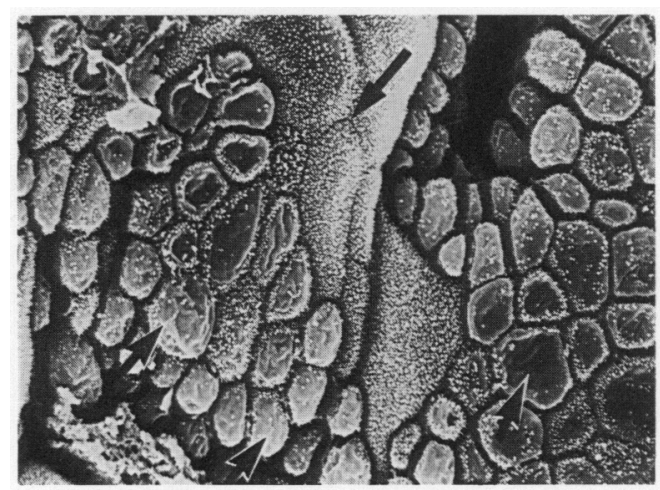

Fig. 8. Scanning electron micrograph of a Day $14+7$ uterine epithelium. The typical domeshaped protrusions of the cells are nearly free from microvilli (arrows), whereas the symplasms (big arrow) are densely covered with microvilli. $\times 330$.

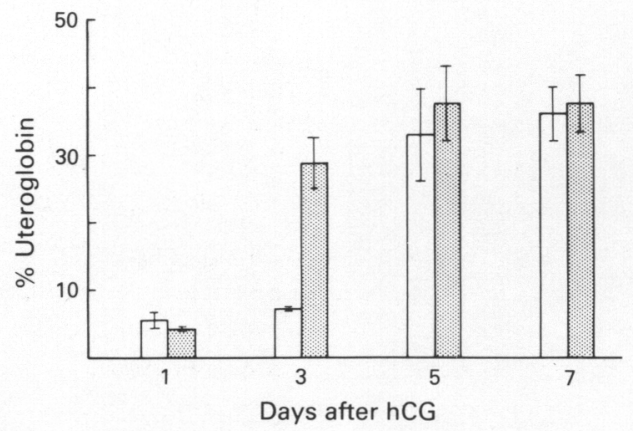

Fig. 9. Uteroglobin (as \% of total protein) in uterine flushings from normal pseudopregnant rabbits $(\square)$ and from rabbits in which a second ovulation was induced between Days 14 and 18 of pseudopregnancy (圈). Data from all animals investigated (see Fig. 1) are pooled. Values are means \pm s.e.m. from 7 ( $\square$ ) and 17 (國) rabbits on Day 1;2 and 10 on Day 3;2 and 4 on Day 5; and 2 and 4 on Day 7 , respectively.

$P<0.01$ ). The early rise in uteroglobin was confined to Day 3; no statistically significant differences were found on Days 1, 5 or 7 after the second hCG injection compared to normal pseudopregnancy. If, however, the various days of pseudopregnancy were considered separately, striking differences occurred between Day 14 and Days 15-18 (Fig. 10). In all animals of the Day 14 series (Days $14+1$, $+3,+5,+7)$, lower uteroglobin concentrations were found, particularly on Day $14+3(P<0.01)$. Advanced endometrial transformation, demonstrable morphologically as well as biochemically, therefore occurred in the rabbit when this transformation was induced in later stages of pseudopregnancy, but only if ovulation was induced later than Day 15.

\section{Plasma progesterone and oestradiol}

Plasma progesterone concentrations were still elevated on Days 14 and $15(P<0.001 ;$ Fig. 11$)$, but decreased as early as 1 day after ovulation (Days 14-18 +1 ; Fig. 12). The progesterone 
concentrations did not fall to the basal values found on Days 16,17 and 18 or in untreated nonpregnant controls (Fig. 11). Compared to rabbits in the Day 18 series, Day 14 does showed higher progesterone concentrations $(P<0.05)$ at 5 and 7 days after second ovulation. The low uteroglobin secretion on Day $14+3$ (Fig. 10) was not reflected by lower progesterone concentrations.

Oestradiol concentrations in blood plasma were quite variable and seemed to be unaffected by progestational stage (Figs $11 \& 12$ ). On Day 14 of pseudopregnancy only, constantly but not statistically significant lower values were found $(P>0.05$; Fig. 11). After hCG injection, higher concentrations, but again not statistically significant, were observed in all Day 14 groups (Days 14 $+1,+3,+5,+7)$ compared to Days 16 and 18 .

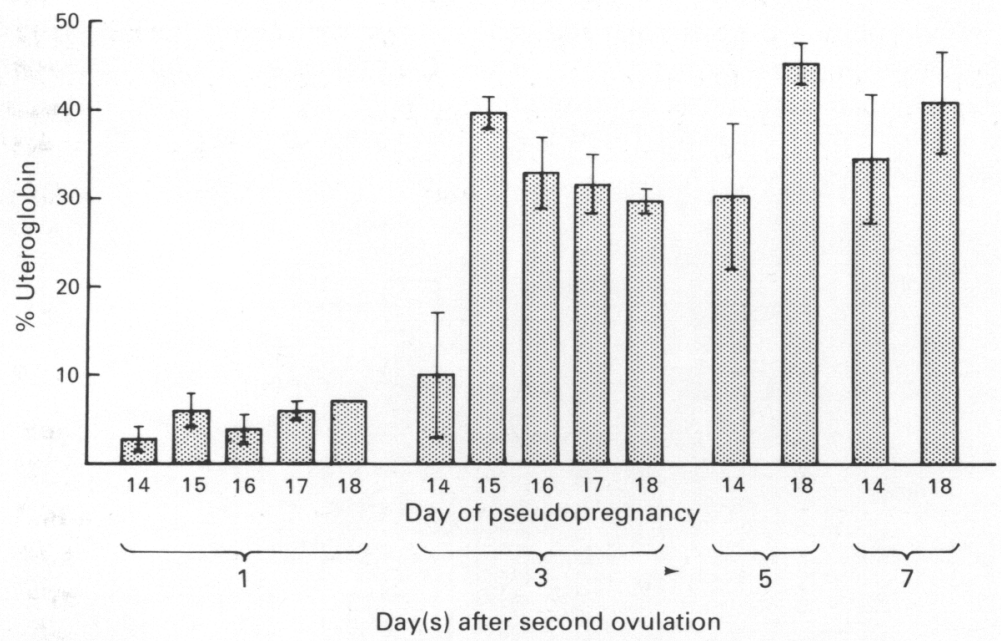

Fig. 10. Uteroglobin (as \% of total protein) in uterine flushings from rabbits in which ovulation was induced between Days 14 and 18 of pseudopregnancy. Separate data for all groups investigated (see Fig. 1) are shown. Values are means \pm s.e.m.; number of rabbits 5 for Days $14+1$ and $15+1$, and 2 for all other groups.

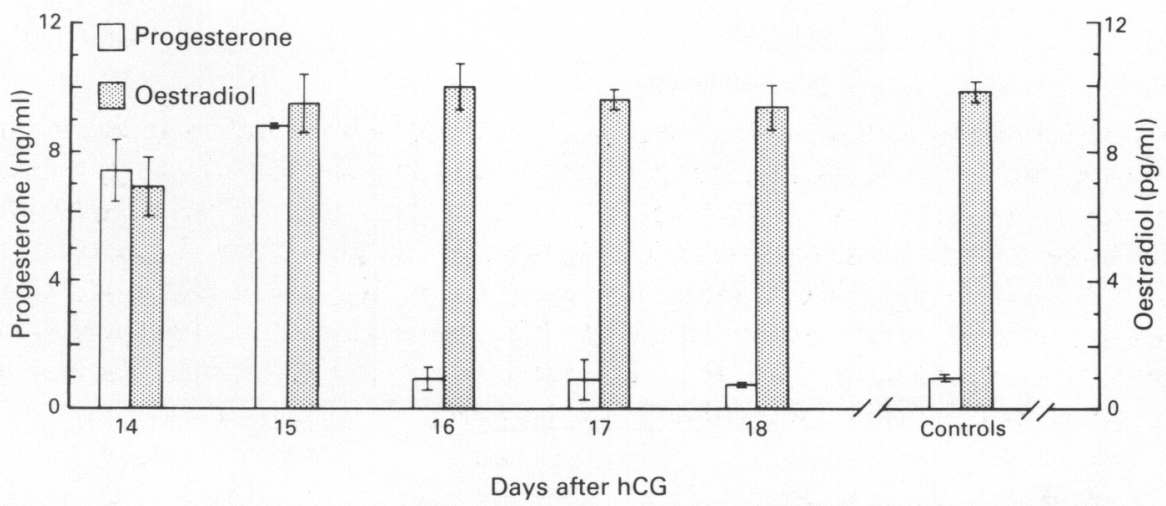

Fig. 11. Peripheral plasma progesterone and oestradiol concentrations in pseudopregnant rabbits. Control values were measured before treatment in nonpregnant, nonpseudopregnant rabbits. Values are means \pm s.e.m. for 3 does/day of pseudopregnancy. 


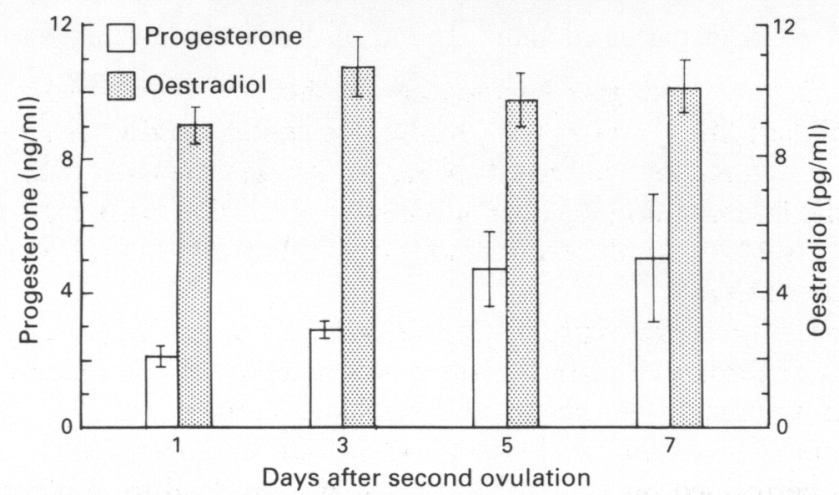

Fig. 12. Peripheral plasma progesterone and oestradiol concentrations in rabbits in which a second ovulation was induced between Days 14 and 18 of pseudopregnancy. Cumulative data of all animals investigated are shown at various days after the second hCG injection. Values are means \pm s.e.m. for 9 does on Days 1 and 3 and for 6 does on Days 5 and 7 after second ovulation, respectively.

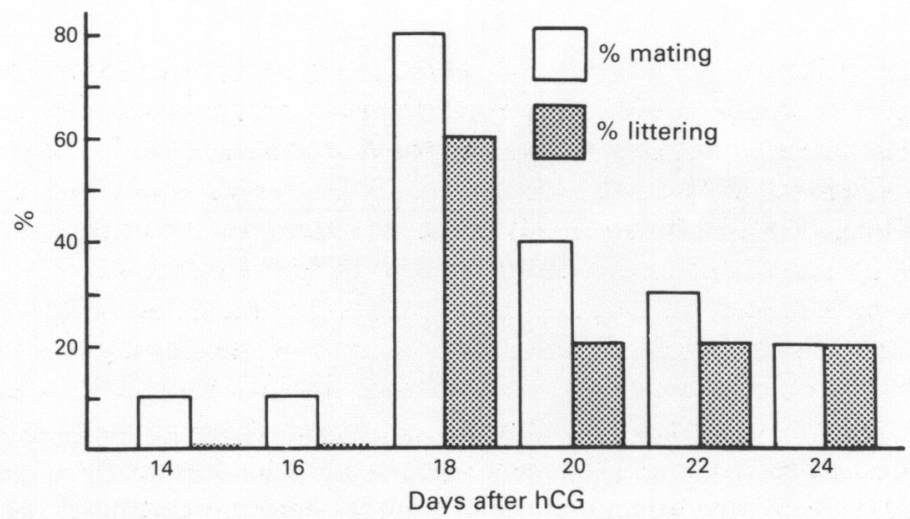

Fig. 13. Mating and littering rates in rabbits mated between Days 14 and 24 of pseudopregnancy (10 does/day of pseudopregnancy).

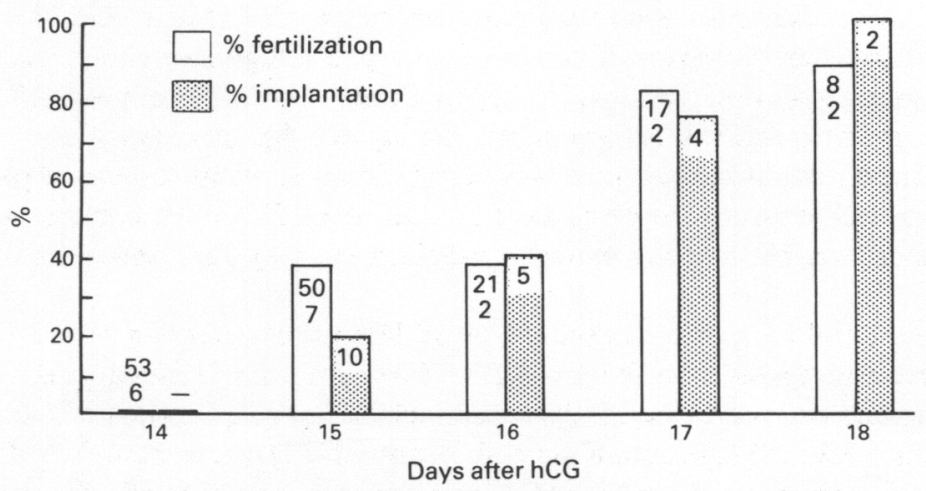

Fig. 14. Fertilization (examined $28 \mathrm{~h}$ after $\mathrm{AI}$ ) and implantation rates (examined 12 days after AI) in rabbits artificially inseminated (AI) between Days 14 and 18 of pseudopregnancy. The numbers in the open columns represent the no. of eggs examined and the no. of does; those in stippled columns the no. of does examined. 


\section{Fertility}

As shown in Fig. 13, most matings in late pseudopregnancy were recorded on Day 18 after hCG and resulted in the highest litter rates as well. Mating percentage and litter size decreased at later times. Although a few matings were observed earlier, no young were born to animals mated before Day 18. After artificial insemination, fertilization and implantation occurred 3 days earlier, i.e. at Day 15, but not on Day 14 of pseudopregnancy (Fig. 14). The best rates, however, were obtained on Days 17 and 18 after hCG.

To investigate the reasons for reproductive failure on Day 14 of pseudopregnancy and to discriminate between disturbances of fertilization and inability of the uterine milieu to support preimplantational embryonic development, we performed embryo transfers on Day $14+1$ (75 embryos transferred into 6 recipients) and Day $14+3$ (48 embryos transferred into 5 recipients). In contrast to transfers performed on Day $14+1$ which did not lead to implantation, $38 \%$ of the transferred embryos did implant in 3 recipients when transferred 3 days after induction of ovulation on Day 14. From these pregnancies, normal living young were delivered by Caesarian operation on Day 29.

\section{Discussion}

The lifespan of corpora lutea in pseudopregnant rabbits has been reported to last about 17 days after hCG injection (Scott \& Rennie, 1970). However, declining progesterone concentrations suggest that luteolysis starts earlier, about Day 12 (Harrington \& Rothermel, 1977; Ellinwood et al., 1979; Caillol, Dauphin-Villemant \& Martinet, 1983), Day 13 (Browning et al., 1980), or Day 14 after hCG (Carison \& Gole, 1978). Hoffman (1974) found morphologically intact corpora lutea on Day 13. Quatacker (1982) noticed the first histological signs of luteal regression at 12 days after hCG and these became pronounced on Day 16. Since endocrinological and morphological data are contradictory, we tried to identify the functional breakdown of pseudopregnancy in the rabbit.

Regarding termination of pseudopregnancy, various findings have to be kept in mind. As is known from light microscopical (Fischer, Winterhager, Busch \& Beier, 1985) and electron microscopical investigations (Busch et al., 1986), clear signs of epithelial regeneration are observed in the endometrium on Day 16 of pseudopregnancy. This observation correlates well with the decline in progesterone concentrations found in the present study (Fig. 11). The predominant uterine secretion protein during preimplantation in the rabbit, uteroglobin (Beier, 1967, 1968; Krishnan \& Daniel, 1967), decreases after Day 10 (Johnson, 1972) or Day 12 (Fischer et al., 1985). Mating behaviour and fertility (Fig. 13) indicate an oestrous period about Day 18 after hCG. This finding is confirmed by changes in sexual behaviour from unreceptive to a high rate of acceptance of males by pseudopregnant animals, as described previously by Caillol, Solari \& Lefebvre (1984), and also by typical behaviour patterns such as nest-building activity and fur plucking which can be observed after unsuccessful matings about that time. We would therefore define the end of pseudopregnancy in the rabbit by functional criteria as being Day 18 after hCG. However, oestrus cannot be defined by morphological criteria because the uterine epithelium on Day 18 is still not restored (Busch et al., 1986).

Regarding the period of epithelial restoration in late pseudopregnancy and its physiological consequences, three findings seem to be remarkable. Firstly, a normal pseudopregnant endometrial transformation as described previously (Beier \& Kühnel, 1973, 1976; Davies \& Hoffman, 1973, 1975; Suzuki \& Tsutsumi, 1980, 1981; Busch, Kühnel \& Mootz, 1981) can be achieved after induction of ovulation during this period, i.e. from Day 16 of pseudopregnancy onwards. Secondly, fertilization is found as early as Day 15, but not on Day 14, if the missing mating response is overcome by AI (Fig. 14). Thirdly, endometrial transformation allowing implantation can be initiated as early as Day 14 (see transfers on Day $14+3$ ), but in this case the progestational endometrium shows clear 
differences in morphology (Figs 2, 3, 4,6) and secretory activity (Fig. 10) compared to normal preimplantational endometrium. In the Day 14 group, large symplasms and a broad tight junctional belt, normally most developed between Day 7 and Day 14 of pseudopregnancy (Fischer et al., 1985; Busch et al., 1986), are still present 3 days after the second hCG injection. Thin sections, however, reveal an enhanced transformation of symplasms by karyolysis. On Day $14+7$, the normal Day 7 features of the uterine epithelium are restored, with newly formed symplasms and tight junctional strands which proliferate up to the basal portion of the lateral membrane (Winterhager \& Kühnel, 1982; Winterhager et al., 1984).

Enhanced luteal breakdown after ovulation on Day 14 is indicated by the steep decline in progesterone if concentration on Day 15 of normal pseudopregnancy (Fig. 11) is compared with the level on Day $14+1$ of $2 \cdot 2 \pm 0 \cdot 7 \mathrm{ng} / \mathrm{ml}$. Finally, in contrast to the generally advanced secretion of uteroglobin 3 days after ovulation (Fig. 9), uteroglobin profiles stay low if ovulation is induced on Day 14 of pseudopregnancy (Fig. 10). The lower uteroglobin levels in the Day 14 animals may be explained by the large number of symplasms in uterine epithelium which may be less active in secretion. This would generally be in accord with findings of the inactivity of placental symplasms regarding protein synthesis (Kaufmann, 1983; Kaufmann, Nagl \& Fuhrmann, 1983). Another reason could be an unrestored secretion phase as mentioned by Davies \& Hoffman $(1973,1975)$.

An accelerated transformation of the endometrium occurred. On Days 16 and 18 after hCG, morphology is characterized by the persistence of degenerated cell remnants from the preceding cycle (Busch et al., 1986). An appropriate ultrastructure, however, is restored within a few days after ovulation during this period. The accelerated transformation is sufficient to permit normal implantation as documented by the results after AI (Fig. 14) and embryo transfer, the latter even in animals of the Day 14 series (see Day $14+3$ recipients).

Fertilization does not occur on Day 14 (Fig. 14) or 12 h later (no fertilization in 43 eggs from 5 does). On Day 15, however, $38 \%$ fertilized eggs (Fig. 14) and $20 \%$ does with implantation indicate that a limited period of functional change has appeared at this stage of pseudopregnancy. An insufficient milieu for embryonic development in the Day 14 group is indicated by the fact that embryos transferred on Day $14+1$ did not implant. Failure of fertilization on Day 14 and of implantation on Day $14+1$ may be caused by progesterone dominance before ovulation (Chang, 1950; Kennelly \& Foote, 1965; Nutting \& Mares, 1970; Chang, 1976; Vargas \& Pauerstein, 1976). On Day $14+1$, an advanced transport to a hostile uterus of the tubally transferred eggs might be involved (Adams, 1968; Glass, 1972; Takeda, Suzuki, Matsui, Terami \& Tsutsumi, 1978). In an experiment comparable to our study, Adams (1968) noticed an accelerated tubal egg transport after ovulation induced in pregnant rabbits.

Transfers to the uterus performed on Day $14+3$ led to embryo survival and implantation. Consideration of uterine morphology with widespread cell destruction at the time of transfer (Figs $2,3,4,6$ ) adds a new aspect to our previous understanding of the synchronization demands in this species (Chang, 1950; Hafez, 1963; Adams, 1974; Beier, 1974). In addition to successful post-partum breeding (Adams, 1967; Harned \& Casida, 1969; Foxcroft \& Hasnain, 1973), the Day $14+3$ uterus provides another example where rabbit embroys can develop and implant in a milieu characterized by rapid endometrial regeneration. Synchronization between mother and embryo in the rabbit does not therefore require a morphologically properly proliferated 'synchronous' endometrium throughout preimplantation. The examination of features other than morphology may lead to a better understanding of the basic mechanisms for synchronization before implantation.

We thank Barbara Bonn, Thomas Jung, Gisela Mathieu, Gabi Meuser-Odenkirchen, Dr Ursula Mootz, Karin Pfleger, and Diana Seelis for valuable assistance; Professor Henning M. Beier, Professor Jerry A. Mitchell, and Dr Joy I. Mulholland for critically reading the manuscript; and the Endocrinological Laboratory of the Department of Obstetrics \& Gynecology, Medical Faculty, 
RWTH Aachen, for performing the hormone assays. Support was provided from the Deutsche Forschungsgemeinschaft within the special research programme on 'Biologie und Klinik der Reproduktion'.

\section{References}

Adams, C.E. (1967) Concurrent lactation and pregnancy in the rabbit. $J$. Reprod. Fert. 14, 351-352, Abstr.

Adams, C.E. (1968) Ovarian response to human chorionic gonadotrophin and egg transport in the pregnant and post-parturient rabbit. J. Endocr. 40, 101-105.

Adams, C.E. (1974) Asynchronous egg transfer in the rabbit. J. Reprod. Fert. 35, 613-614, Abstr.

Arnold, R. \& Shorey, C.D. (1984) Structural and morphometric changes in the uterine epithelium of the rabbit during the later stages of gonadotrophin-induced pseudopregnancy. J. Anat. 139, 201, Abstr.

Beier, H.M. (1967) Veränderungen am Proteinmuster des Uterus bei dessen Ernährungsfunktion für die Blastocyste des Kaninchens. Verh. Disch. Zool. Ges. 31, 139-148.

Beier, H.M. (1968) Uteroglobin: a hormone-sensitive endometrial protein involved in blastocyst development. Biochim. Biophys. Acta 160, 289-291.

Beier, H.M. (1974) Oviducal and uterine fluids. $J$. Reprod. Fert. 37, 221-237.

Beier, H.M. (1982) Uteroglobin and other endometrial proteins: biochemistry and biological significance in beginning pregnancy. In Proteins and Steroids in Early Pregnancy, pp. 39-71. Eds H. M. Beier \& P. Karlson. Springer, Berlin.

Beier, H.M. \& Kühnel, W. (1973) Pseudopregnancy in the rabbit after stimulation by human chorionic gonadotropin. Hormone Res. 4, 1-27.

Beier, H.M. \& Kühnel, W. (1976) Untersuchungen zur funktionellen Morphologie des Epithels der Endosalpinx und des Endometriums. Verh. Anat. Ges. 70, 83 I-838.

Browning, J.Y., Keyes, P.L. \& Wolf, R.C. (1980) Comparison of serum progesterone, $20 \alpha$-dihydroprogesterone, and estradiol-17 $\beta$ in pregnant and pseudopregnant rabbits: evidence for postimplantation recognition of pregnancy. Biol. Reprod. 23, 1014-1019.

Busch, L.C., Kühnel, W. \& Mootz, U. (1981) Scanning electron microscopical studies of the rabbit endometrium during estrus and preimplantation. In Three Dimensional Microanatomy of Cells and Tissue Surfaces, pp. 267-278. Eds D. J. Allen, P. M. Motta \& L. J. A. Didio. Elsevier/North Holland, Amsterdam.

Busch, L.C., Winterhager, E. \& Fischer, B. (1986) Regeneration of the uterine epithelium in later stages of pseudopregnancy in the rabbit. An ultrastructural study. Anat. Embryol. 174, 97-104.

Caillol, M., Dauphin-Villemant, C. \& Martinet, L. (1983) Oestrous behaviour and circulating progesterone and oestrogen levels during pseudopregnancy in the domestic rabbit. J. Reprod. Fert. 69, 179-186.

Caillol, M., Solari, A. \& Lefebvre, J. (1984) Changes in steroid concentrations in follicular fluid and sexual behaviour during pseudopregnancy in the rabbit. Reprod. Nutr. Dévelop. 24, 95-105.
Carlson, J.C. \& Gole, J.W.D. (1978) CL regression in the pseudopregnant rabbit and the effects of treatment with prostaglandin $\mathrm{F}-2 \alpha$ and arachidonic acid. $J$. Reprod. Fert. 53, 381-387.

Chang, M.C. (1950) Development and fate of transferred rabbit ova or blastocysts in relation to the ovulation time of recipients. J. exp. Zool. 114, 197-216.

Chang, M.C. (1976) Estrogen, progesterone and egg transport-overview and identification of problems. In Ovum Transport and Fertility Regulation, pp. 473-484. Eds M. J. K. Harper, C. J. Pauerstein, C. E. Adams, E. M. Coutinho, H. B. Croxatto \& D. M. Paton. Scriptor, Copenhagen.

Davies, J. \& Hoffman, L.H. (1973) Studies on the progestational endometrium of the rabbit. I. Light microscopy, day 0 to day 13 of gonadotropin-induced pseudopregnancy. Am. J. Anat. 137, 423-446.

Davies, J. \& Hoffman, L.H. (1975) Studies on the progestational endometrium of the rabbit. II. Electron microscopy, day 0 to day 13 of gonadotropin-induced pseudopregnancy. Am. J. Anat. 142, 335-366.

Ellinwood, W.E., Seidel, G.E., Jr \& Niswender, G.D. (1979) Secretion of gonadotropic factors by the preimplantation rabbit blastocyst. Proc. Soc. exp. Biol. Med. 161, 136-141.

Fischer, B., Winterhager, E., Busch, L.C. \& Beier, H.M. (1985) Die Pseudogravidität des Kaninchens als reproduktionsbiologisches Modell. Fertilität 1, 101-109.

Foxcroft, G.R. \& Hasnain, H.C. (1973) Effects of suckling and time to mating after parturition on reproduction in the domestic rabbit. J. Reprod. Fert. 33, 367-377.

Glass, R.H. (1972) Fate of rabbit eggs fertilized in the uterus. J. Reprod. Fert. 31, 139-141.

Hafez, E.S.E. (1963) Effect of progestational stage of the endometrium on implantation, fetal survival and fetal size in the rabbit, Oryctolagus cuniculus. J. exp. Zool. 151, 217-226.

Harned, M.A. \& Casida, L.E. (1969) Some postpartum reproductive phenomena in the domestic rabbit. $J$. Anim. Sci. 28, 785-788.

Harrington, F.E. \& Rothermel, J.D. (1977) Daily changes in peripheral plasma progesterone concentrations in pregnant and pseudopregnant rabbits. Life Sciences 20, 1333-1340.

Hilliard, J. (1973) Corpus luteum function in guinea pigs, hamsters, rats, mice and rabbits. Biol. Reprod. 8 , $203-221$.

Hofiman, L.H. (1974) Luteal regression induced by arachidonic acid in the pseudopregnant rabbit. $J$. Reprod. Fert. 36, 401-404.

Johnson, M.H. (1972) The protein composition of secretions from pregnant and pseudopregnant rabbit uteri with and without a copper intrauterine device. Fert. Steril. 23, 123-130. 
Kaufmann, P. (1983) Vergleichend-anatomische und funktionelle Aspekte des Placenta-Baues. Funkt. Biol. Med. 2, 71-79.

Kaufmann, P., Nagl, W. \& Fuhrmann, B. (1983) Die funktionelle Bedeutung der Langhanszellen der menschlichen Placenta. Verh. Anat. Ges. 77, 435-436.

Kennelly, J.J. \& Foote, R.H. (1965) Superovulatory response of pre- and postpubertal rabbits to commercially available gonadotrophins. J. Reprod. Fert. 9, $177-188$.

Krishnan, R.S. \& Daniel, J.C., Jr (1967) Blastokinin: inducer and regulator of blastocyst development in the rabbit uterus. Science, $N . Y$. 158, 490-492.

Maurer, H.R. (1971) Disc Electrophoresis and Related Techniques of Polyacrylamide Gel Electrophoresis. de Gruyter, Berlin.

Maurer, R.R. (1978) Advances in rabbit embryo culture. In Methods in Mammalian Reproduction, pp. 259-272. Ed. J. C. Daniel, Jr. Academic Press, New York.

Nutting, E.F. \& Mares, S.E. (1970) Inhibition of fertilization in rabbits during treatment with progesterone. Biol. Reprod. 2, $230-238$.

Quatacker, J.R. (1982) Ultrastructural observations on rabbit luteal cells and interstitial gland cells during pseudopregnancy. In Proteins and Steroids in Early Pregnancy, pp. 27-38. Eds H. M. Beier \& P. Karlson. Springer, Berlin.

Schlegel, W., Fischer, B., Beier, H.M. \& Schneider, H.P.G. (1983) Effects of fertilization of rabbits of insemination with ejaculates treated with PGdehydrogenase and antisera to PGE-2 and PGF-2 $\alpha$. J. Reprod. Fert. 68, 45-50.
Scott, R.S. \& Rennie, P.J.C. (1970) Factors controlling the life-span of the corpora lutea in the pseudopregnant rabbit. J. Reprod. Fert. 23, 415-422.

Suzuki, H. \& Tsutsumi, Y. (1980) Morphological changes of uterine and cervical epithelium during early pseudopregnancy in rabbits. J. Fac. Agr. Hokkaido Univ. 60, 47-61.

Suzuki, H. \& Tsutsumi, Y. (1981) Morphological studies of uterine and cervical epithelium in pseudopregnant rabbits. J. Fac. Agr. Hokkaido Univ. 60, 123-132.

Takeda, T., Suzuki, H., Matsui, S., Terami, Y.\& Tsutsumi, Y. (1978) Effects of progesterone and medroxyprogesterone acetate on egg recovery from the vagina of rabbits. Jap. J. Anim. Reprod. 24, 184-191.

Vargas, de, M.I.G. \& Pauerstein, C.J. (1976) Influence of timing and dose of progesterone on ovum transport rates. In Ovum Transport and Fertility Regulation, pp. 515-526. Eds M. J. K. Harper, C. J. Pauerstein, C. E. Adams, E. M. Coutinho, H. B. Croxatto \& D. M. Paton. Scriptor. Copenhagen.

Winterhager, E. \& Kühnel, W. (1982) Alterations in intercellular junctions of the uterine epithelium during the preimplantation phase in the rabbit. Cell Tissue Res. 224, 517-526.

Winterhager, E., Busch, L.C. \& Kühnel, W. (1984) Membrane events involved in fusion of uterine epithelial cells in pseudopregnant rabbits. Cell Tissue Res. 235 , 357-363. 